\title{
Modelling the potential risk zone of Lantana camara invasion and response to climate change in eastern India
}

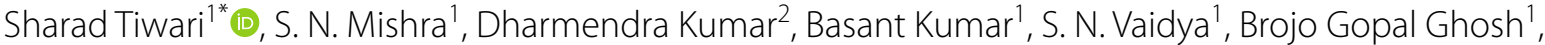 \\ Sk Mujibar Rahaman', Masjuda Khatun', Sanjoy Garai ${ }^{1}$ and Amit Kumar ${ }^{3}$ (B)
}

\begin{abstract}
Background: The aim of this study is to elucidate the potential risk zones prone to the invasion of perennial ornamental plant Lantana camara, which is native to South America and has invasive tendency in Jharkhand, eastern India, for present (2020) and the future (2050) climatic conditions under four different Representative Concentration Pathways scenarios (RCPs). We analysed the current distribution pattern of L. camara in the plateau region of eastern India and identified potentially suitable habitats prone to its further infestation in the future under the climate change scenario.

Results: Results showed the presence of L. camara invasion in $\sim 13 \%$ of the geographical area of Jharkhand, Chotanagpur plateau which may expand up to $20-26 \%$ by 2050 depending upon emission scenarios as characterised by the four RCPs. Analysis for the current scenario suggests the dominance of $L$. camara in sub-zone V (12.77\% under high risk zones (HRZ) and 9.5\% under critical risk zones (CRZ)) followed by sub-zones IV (6.7\%: HRZ; 4.19\%: CRZ) and VI (2.49\%: HRZ; 2.14\%: CRZ). Future projection (2050) indicates a possible expansion of its distribution range across all agro-climatic sub-zones with dominance in sub-zones V and IV. Variable Bio_4 (temperature seasonality) was observed as the most contributing factor for the distribution of $L$. camara for current and future scenarios across all RCPs. Suitable habitat for L. camara mostly occurred under natural vegetation (66.05\% of CRZ and $60.71 \%$ of HRZ) and agriculture landscape (29.51\% of CRZ and $34.48 \%$ of HRZ).
\end{abstract}

Conclusions: The study provides an insight of invasion of L. camara in the plateau region of eastern India, and reveals wide distribution across all the agro-climatic sub-zones of Jharkhand, mostly in open and disturbed areas under natural vegetation and agriculture landscapes. Future projections for the year 2050 suggest a continuous increase in the expansion range of invasion across Jharkhand and call for urgent initiatives to combat its further invasion.

Keywords: Climate change, Forest, Invasion, Lantana camara, Maxent, RCPs

\section{Background}

Lantana camara of the Verbenaceae family has more than 600 varieties and is a native terrestrial weed of South and Central American origin, which is considered among the top 10 worst invasive species by IUCN.

\footnotetext{
*Correspondence: sharadtiwari8@gmail.com; tiwaris@icfre.org

${ }^{1}$ Institute of Forest Productivity, Lalgutwa, Ranchi 835303, Jharkhand, India

Full list of author information is available at the end of the article
}

It severely affects the native composition of terrestrial ecosystems (Swarbrick 1986; IUCN 2001). L. camara, a short height shrub, attains heights to $1.2-2.4 \mathrm{~m}$, ovateoblong, opposite, rugged, and a bit hairy leaf structure. The species was introduced in India in 1809 (Kohli et al. 2006) and later invaded most of disturbed forest, pasture and fallow landscapes, with an estimated cost of US\$ 70 per hectare for its control (Negi et al. 2019). The $L$. camara distribution has adversely impacted the population stratification, regeneration, and anticipated 
future composition of tree communities in tropical dry deciduous forests of India (Sharma and Raghubanshi 2006). The species due to its wide eco-tolerance (Negi et al. 2019) has dominated varied landscapes including disturbed areas (Richardson et al. 2004), along streams (Ramaswami and Sukumar 2014) open and disturbed forests (Raghubanshi and Tripathi 2009) and riparian vegetation (Meek et al. 2010; Dobhalet al. 2011). L. camara spread contributed to a $50 \%$ decrease in livestock forage, diminished natural resources, and obstructed human and livestock movements (Shackleton et al. 2017). Lantana occupies a wide category of habitats and varied soil types (Sharmaet al. 2005), and disperses mostly through frugivorous birds (Hariharan 2017), anthropogenic factors (Lin 2007), and forest fire (Hiremath and Sundaram 2005). The spread of L. camara stimulates forest fires (Raghubanshi et al. 2005). Improved soil nutrients were observed in western Himalayan forests due to the invasion of L. camara (Singh and Singh 1992). Due to its high regeneration potential and perennial reproduction, L. camara rapidly invades habitats (Daizy et al. 2004). Allelochemical ingredients of $L$. camara adversely affect plant richness (Day et al. 2003).

Habitat suitability models (viz., Maxent, GARP and Biomapper) have been widely used to predict the potential distributions of invasive plant species (Hoffman et al. 2008) and IUCN red-listed species (Rajput et al. 2020; Kumar et al. 2020). For example, about $65 \%$ of the geographical area in the southern province of Zimbabwe may comprise suitable habitat for L. camara by 2070 (Ncube et al. 2020). Investigators have used Maxent to determine the potential distribution of various invasive species viz., Sapium sebiferum in western Himalaya (Jaryanet al. 2013); Chromolaena odorata, L. camara, and Parthenium hysterophorus in the Western Ghats (Patil and Janarthanam 2013). Distance from river and elevation contribute significantly to the prediction of potential distribution zone (Hoffman et al. 2008). In a comparative study to evaluate the model performances of Maxent, GARP and Biomapper for the prediction of the $L$. camara distribution in Jim Corbett and Rajaji National Park, Maxent performed best and was the most reliable for determining the spatial distribution of L. camara (Priyanka and Joshi 2013a).

This literature review suggests that substantial work on L. camara has focused on understanding its impact on native species, distribution, niche conservation, use, and allelopathic effects, etc. (Witt et al. 2018; Goncalves et al. 2014). Evidence from a number of studies suggests that once $L$. camara is established, little can be done to eradicate it (Bhagwat et al. 2012), and hence early detection is the key to addressing invasion issues. In most cases, steps are taken without the proper identification and prioritization of the target site.

The present work aims to understand the existing distribution patterns of L. camara under different agro-climatic conditions in the Chotanagpur plateau and to understand its response to climate change by 2050 under different climatic Representative Concentration Pathway (RCP) scenarios, i.e., 2.6, 4.5, 6.0 and 8.5. This study aims to provide an in-depth analysis on existing distribution pattern and identification of identification of potential distribution sites prone to invasion risk of L. camara, and prioritization of areas for treatment in Jharkhand, a major part of Chotanagpur plateau in eastern India. This would lead to early detection of infestation status and management strategies to curtail the spread of L. camara in advance. The western part of Jharkhand comprising Betla National Park is a tiger reserve and many important forest species with immense medicinal properties existing in this part, and thus it has significant socio-economic aspects.

\section{Materials and methods Study area}

The focus area of the present study, Jharkhand in eastern India, is primarily a plateau (Chotanagpur plateau), located between $25^{\circ} 30^{\prime} \mathrm{N}$ to $22^{\circ} \mathrm{N}$ latitudes, and $83^{\circ} \mathrm{E}$ to $88^{\circ} \mathrm{E}$ in longitudes, comprising $79,714 \mathrm{~km}^{2}$ of geographical area (Fig. 1). Approximately 29.61\% (23,506 km²) of the geographical area is dominated by tropical moist deciduous and tropical dry deciduous forests (FSI 2017). Agro-climatically, there are three sub-zones i.e. IV, V, and VI characterised by humid, tropical, and subtropical climates (Mishra et al. 2021). Being a tribal-dominated state, a large part of the population depends on forest products. The Chotanagpur plateau has a repository of various mineral resources as well as many forest species, with the socio-economic aspect.

\section{Occurrence data}

Occurrence of $L$. camara was recorded from 425 locations of Jharkhand encompassing agro-climatic subzones IV, V, and VI, during the pre- and post-monsoon months of 2016-2018 using a transact method (0.01 ha) in $10 \mathrm{~km} \times 10 \mathrm{~km}$ grids. Geographical coordinates of species occurrences were recorded using GPS (Garmin Oregon) at accuracy $\leq 10 \mathrm{~m}$. At least a $2 \mathrm{~km}$ distance was maintained between two transects to cover representatives approximately uniformly in the entire study area. Verification of some of the potential distribution sites of $L$. camara modelled through the present study was performed during January-February, 2019 for on-theground validation. 


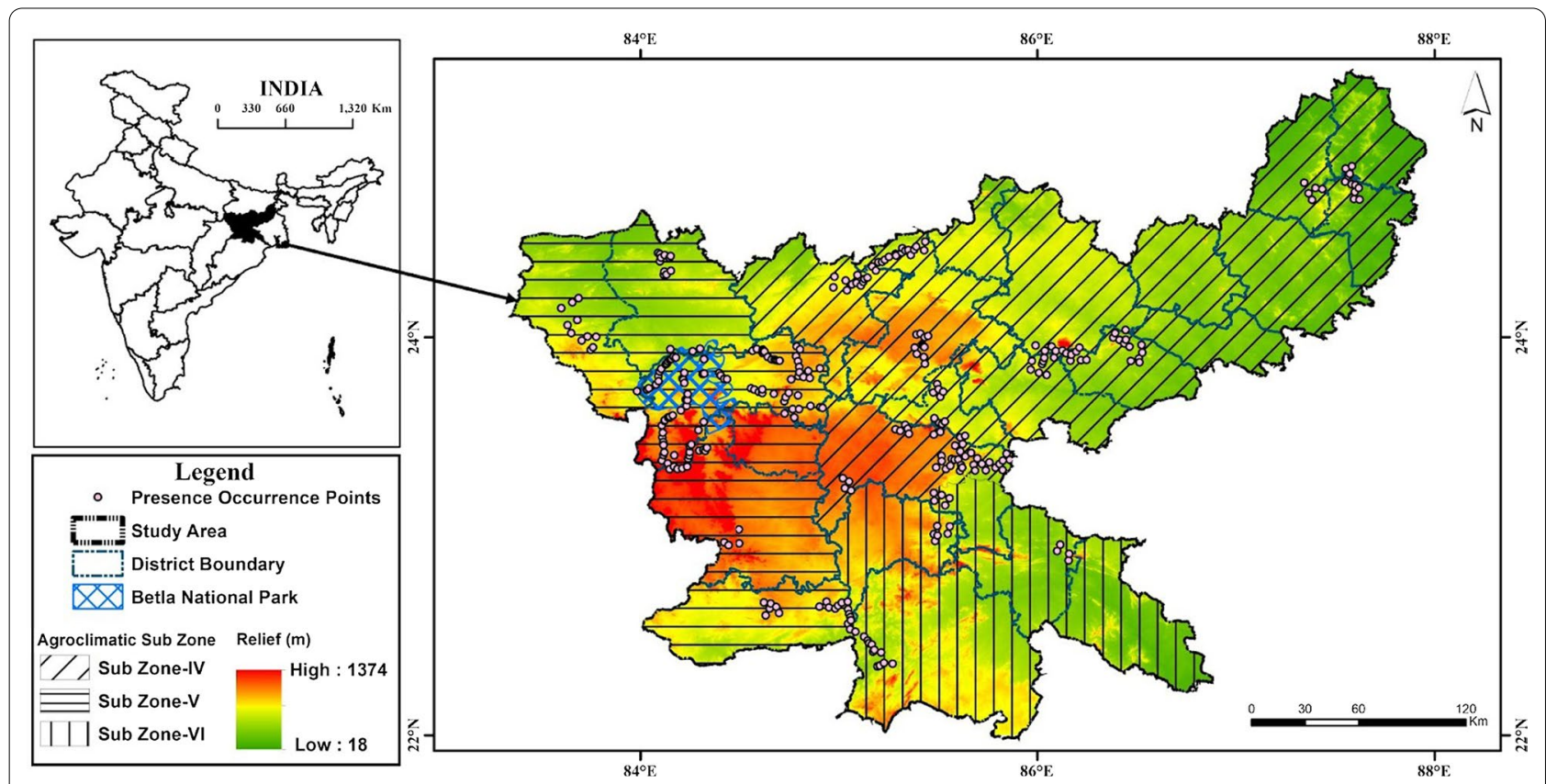

Fig. 1 Location map of the study area encompassing all the three agro-climatic sub-zones viz sub-zones IV, V and VI and Betla National Park. The points representing occurrence distribution locations of $L$. camara recorded across Jharkhand

\section{Environmental variables}

Bioclimatic variables, ranging from Bio_1 to Bio_19 with 30 arc seconds $(\sim 1 \times 1 \mathrm{~km}$ resolution) resolution were acquired from the Worldclim site (www.worldclim.org) and converted to ASCII (or ESRI ASCII) (Fick and Hijmans 2017). We used Shuttle Radar Topography Mission (SRTM) DEM data of 30 arc seconds resolution from the Worldclim site to derive relief, slope, aspect, and hillshade data layers of the study area (Mishra et al. 2019). Food and Agriculture Organization (FAO) soil vector data (http://www.fao.org/geonetwork/srv) was employed as one of the environment variables that influence species distribution (FAO 2003). Prepared land use/land cover (LULC) map of the study area using LANDSAT 8 OLI data with 30-m spatial resolution secured from the United States Geological Survey (USGS) site (https:// earthexplorer.usgs.gov). A total of 9 tiles of LANDSAT OLI images (path/row: 139/043, 139/044, 139/045, $140 / 043,140 / 044,140 / 045,141 / 043,141 / 044$, and $142 / 043)$ with $>5 \%$ cloud coverage were acquired for the Jharkhand state for the year 2018 (October-December). LANDSAT OLI (https://earthexplorer.usgs.gov) was employed to delineate LULC using a support vector machine (SVM) method to classify the study area into 5 major classes viz., natural vegetation, waterbody, builtup, agriculture land and others. The overall accuracy of the classified LULC was $92 \%$ with kappa coefficient 0.88 . The final map was compared with the National Remote Sensing Centre (NRSC) LULC map for 2015-16 (Bhuvan
2021) and found very higher similarity. The environmental variable dataset was resampled to a uniform extent and cell size (30 arc second) using QGIS and converted to ASCII format. The layers for different RCP pathways i.e., 2.6, 4.5, 6.0, and 8.5 in ASCII grid format at 30-s resolution for the year 2050 were acquired from the Climate Change, Agriculture and Food Security data portal (www. ccafs-climate.org) (Navarro-Racines et al. 2020). We used IPSL-CM5A-LR having a resolution of $1.9^{\circ} \times 3.75^{\circ}$ $(96 \times 96 \times$ L39), to simulate climatic scenarios for 2050 . The term $1.9^{\circ} \times 3.75^{\circ}(96 \times 96 \times \mathrm{L} 39)$ represents the low resolution version of the IPSL-CM5A-LR model, where $(96 \times 96 \times$ L39) refers to the model has 96 number of points each on geographical coordinates corresponding to a resolution of $1.9^{\circ} \times 3.75^{\circ}$ in combination with the 39 layers of the atmospheric variables (Dufresne et al. 2013).

\section{Model training and evaluation}

The potential risk zone vulnerable to $L$. camara in Jharkhand, Chotanagpur plateau was modelled using Maxent ver 3.3.3k (Phillips et al. 2020) with input samples (.csv files of occurrence of $L$. camara) for 425 sample locations. The Jackknife test was employed, to estimate the most contributing predictor variable to best fit the model. To evaluate model accuracy, the area under the Receiver Operating Characteristic (ROC) Curve (AUC) was estimated using test data in Maxent. The model was iterated 10 times to assess the threshold, while the random sample test percentage was set to 30 (Fig. 2). 


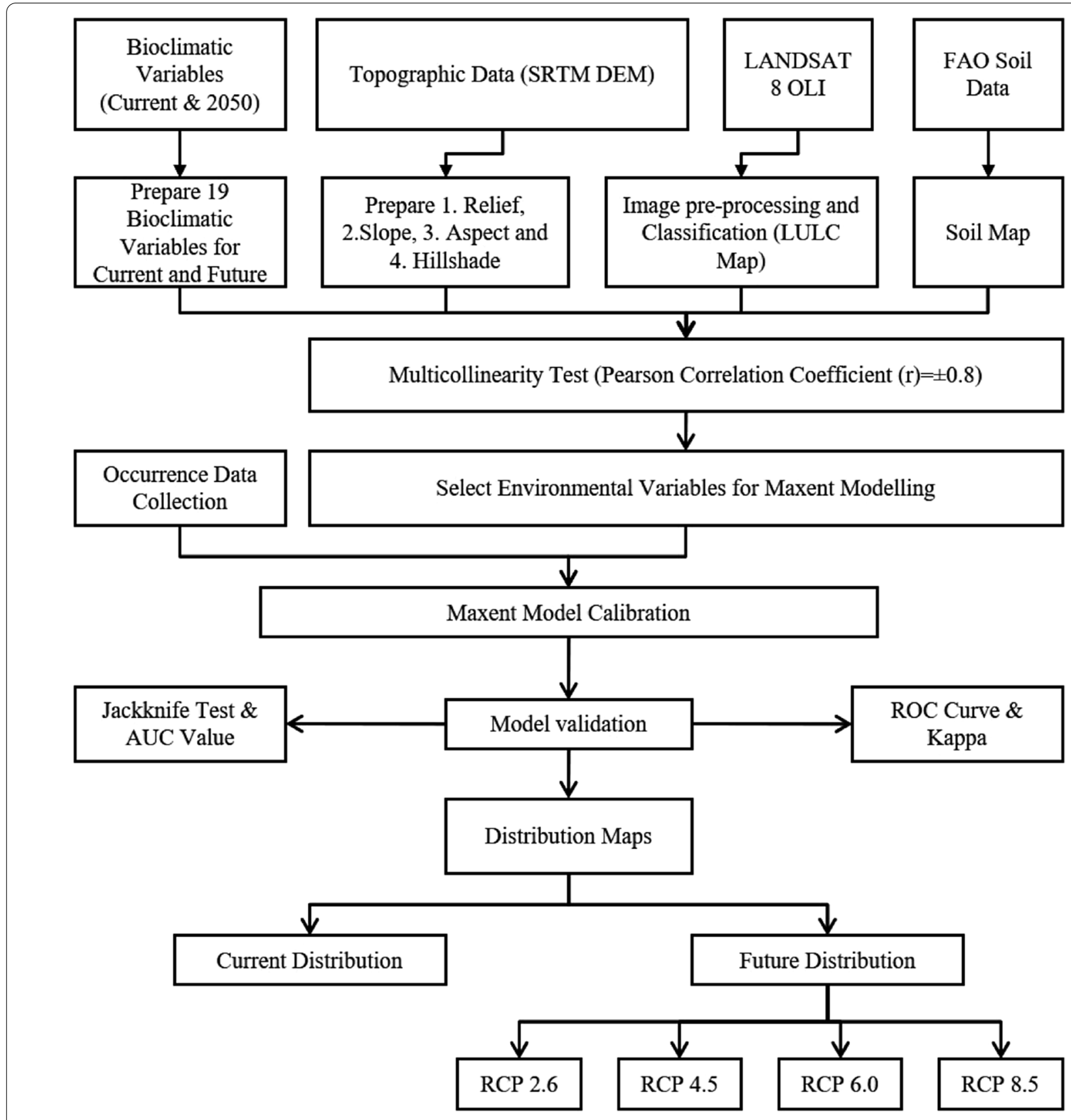

Fig. 2 Flow diagram of the methodology adopted

\section{Delineation of the risk zone area}

Maxent does not categorize the suitability of area in different classes, rather it assigns only the suitable or unsuitable area based on AUC values ranging from 0 to 1 , where AUC value $<0.5$ is considered unsuitable and $>0.5-1$ is considered as suitable. In the present study, the AUCs were classified as low risk $(<0.49)$, high risk (0.5-0.7), and critical risk (>0.7) of L. camara invasion using the geospatial environment analysis. The suitability class is categorised based on the probable risk zones of the selected species (Padalia et al. 2014). The Forest Survey of India (FSI 2017) cover map was utilized to estimate the risk zone area for L. camara distribution under different forest cover classes in the study area.

\section{Model performance and predictor variable analysis}

The potential distribution range map of L. camara was modelled for the current (2020) and future (2050) climatic scenarios under different RCPs i.e., 2.6, 4.5, 6.0, and 8.5. The average test AUC value for 2020 was 0.783 


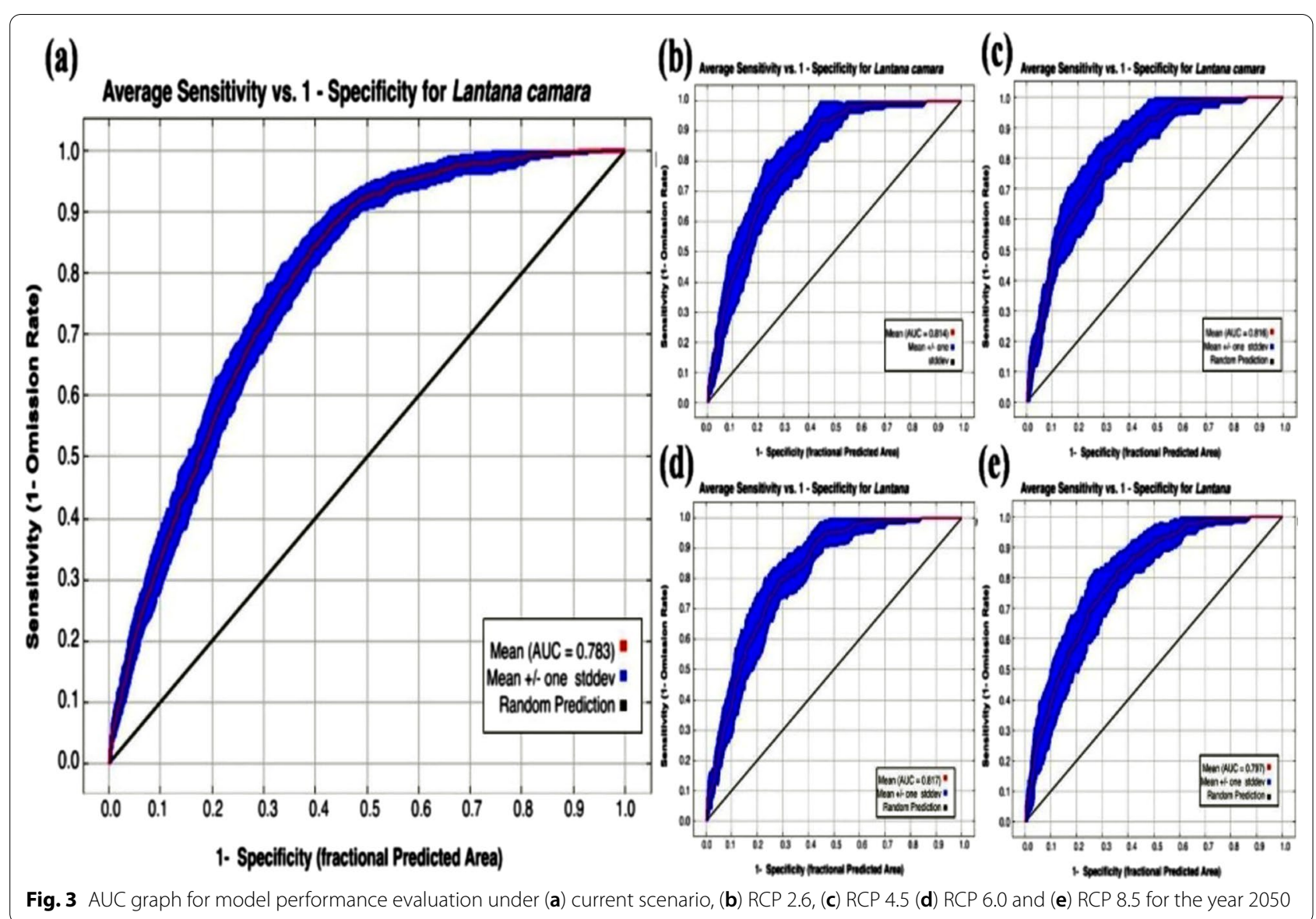

with a standard deviation of 0.017 . For 2050, the calculated average test AUC values were 0.814 with a standard deviation of 0.032 under RCP 2.6, 0.817 with a standard deviation of 0.031 under RCP 4.5, 0.816 with a standard deviation of 0.040 under RCP 6.0 and 0.797 with a standard deviation of 0.035 under RCP 8.5 (Fig. 3).

The Jackknife test analyses for each and every predictor variable contribute to model fitting individually as well as in combination with other variables (Fig. $4 a-e$ ). Depending upon the model gain, the process describes the contribution significance of the predictor variables on their inclusion. The predictor variable analysis shows that variable Bio_4 (temperature seasonality) followed by variable Bio_14 (precipitation of driest month), contributed most under current climatic conditions. For 2050, analysis shows that Bio_4 (temperature seasonality), Bio_7 (temperature annual range) and Bio_9 (mean temperature of the driest quarter) were the major contributing factors for RCP 2.6, 4.5, and 6.0, whereas under scenario RCP 8.5, Bio_4, Bio_2 (mean diurnal range), and Bio_7 were the most influential variables.

\section{Validation and accuracy assessment}

The projected suitable sites for invasion of L. camara in Jharkhand used for validation through physical verification at 38 fresh locations, which were not part of the initial field survey. The calculated overall accuracy was $85 \%$ and Kappa Coefficient 65\%, which shows model strength with high accuracy (Table 1$)$.

\section{Results and discussion}

Distribution pattern of L. camara

Projected potential distribution range in the eastern region

The potential distribution range of $L$. camara was modelled and its distribution patterns were analysed in Jharkhand for the years 2020 and 2050. The results showed that the distribution of $L$. camara led to increasing critical risk in all future scenarios in Jharkhand (7.51-8.18\% of the total area) with a minor decrease under RCP 6.0 (6.87\%) compared to the current scenario (5.25\%) (Fig. 5a-e). The area under high risk comprised a large part of the future climatic scenario across all RCPs (16.25\% under $2.6 ; 13.91 \%$ under $4.5 ; 12.33 \%$ under 6.0 ; and $17.80 \%$ under 8.5 scenario) compared to the current scenario $(7.55 \%$ area). Notably, the high and critical 


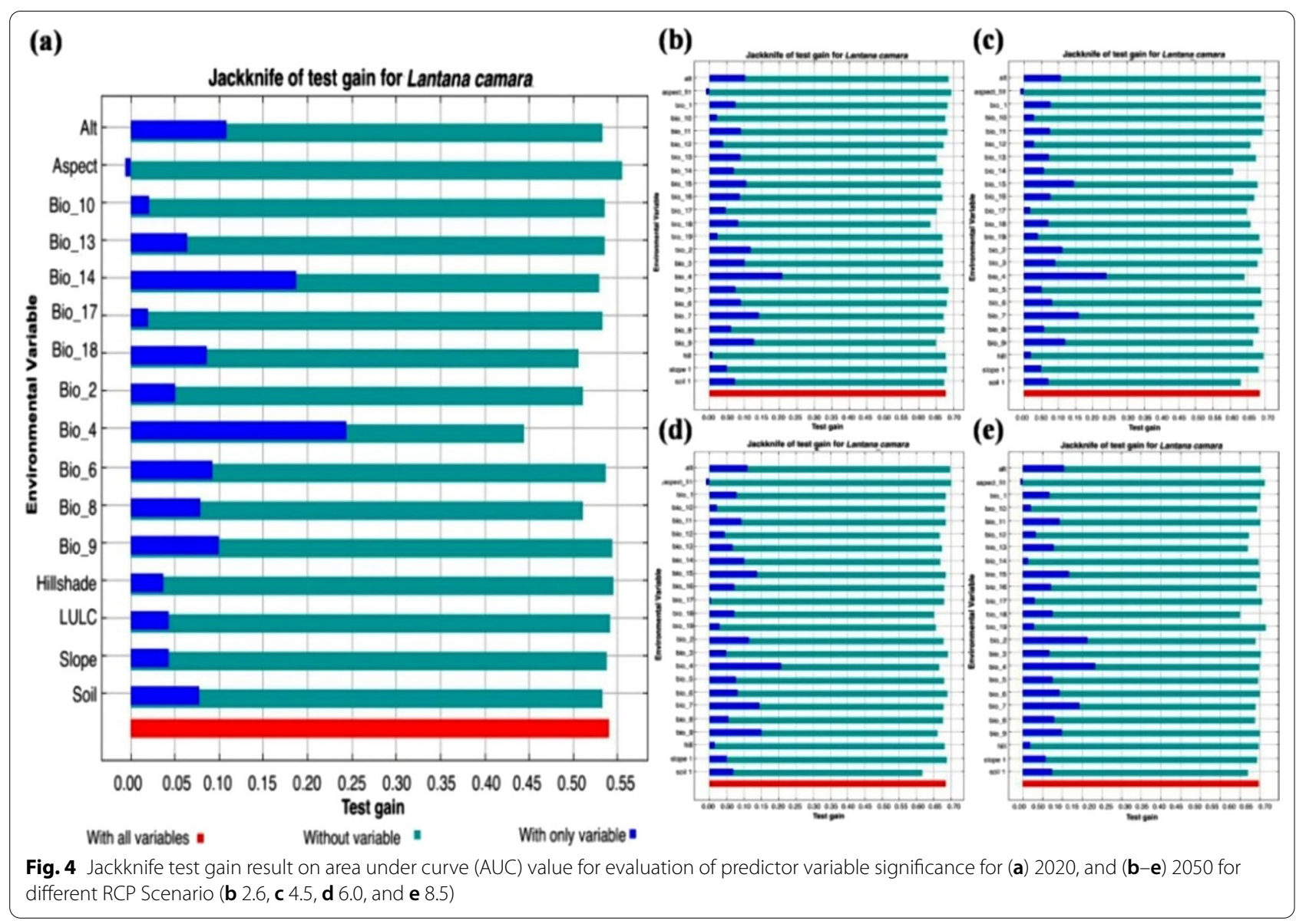

risk to L. camara invasion was projected primarily in the north-western, eastern, and southern parts of Jharkhand state, while the remaining areas were under low risk to invasion in the current $(87 \%)$ and future RCP scenarios (76\% under $2.6 ; 78 \%$ under $4.5 ; 80 \%$ under 6.0 ; and $74 \%$ under 8.5) (Fig. 6).

Predicted potential distribution for a invasion risk of L. camara exhibited approximately similar trends primarily in the north-western and central parts with the lowest invasion in the current scenario in contrast to an increased invasion by 2050, in the large parts $(>20 \%$ geographical area of Jharkhand) in the north-western, and eastern parts, while its dominance and continuous expansion was observed in the existing areas of invasion. This indicates that in the future, about one-fifth of the geographical area of Jharkhand may contain invasion of L. camara, which may have serious implications on the health of native ecosystems (Gooden et al. 2009).

Table 1 Error matrix for validation of projected distribution area of Lantana Camara under different classes

\begin{tabular}{|c|c|c|c|c|c|c|c|}
\hline & \multicolumn{5}{|l|}{ Predicted } & \multirow[b]{2}{*}{ EC } & \multirow[b]{2}{*}{ UA } \\
\hline & & LRZ & HRZ & CRZ & Total $=$ N2 & & \\
\hline \multirow[t]{6}{*}{ Observed } & LRZ & 4 & 4 & 1 & 9 & 0.56 & 0.44 \\
\hline & HRZ & 0 & 2 & 1 & 3 & 0.34 & 0.67 \\
\hline & CRZ & 0 & 0 & 26 & 26 & 0 & 1 \\
\hline & Total $=\mathrm{N} 1$ & 4 & 6 & 28 & $n=38$ & & \\
\hline & $E O$ & 0 & 0.67 & 0.07 & & & \\
\hline & PA & 1 & 0.34 & 0.93 & & & \\
\hline
\end{tabular}



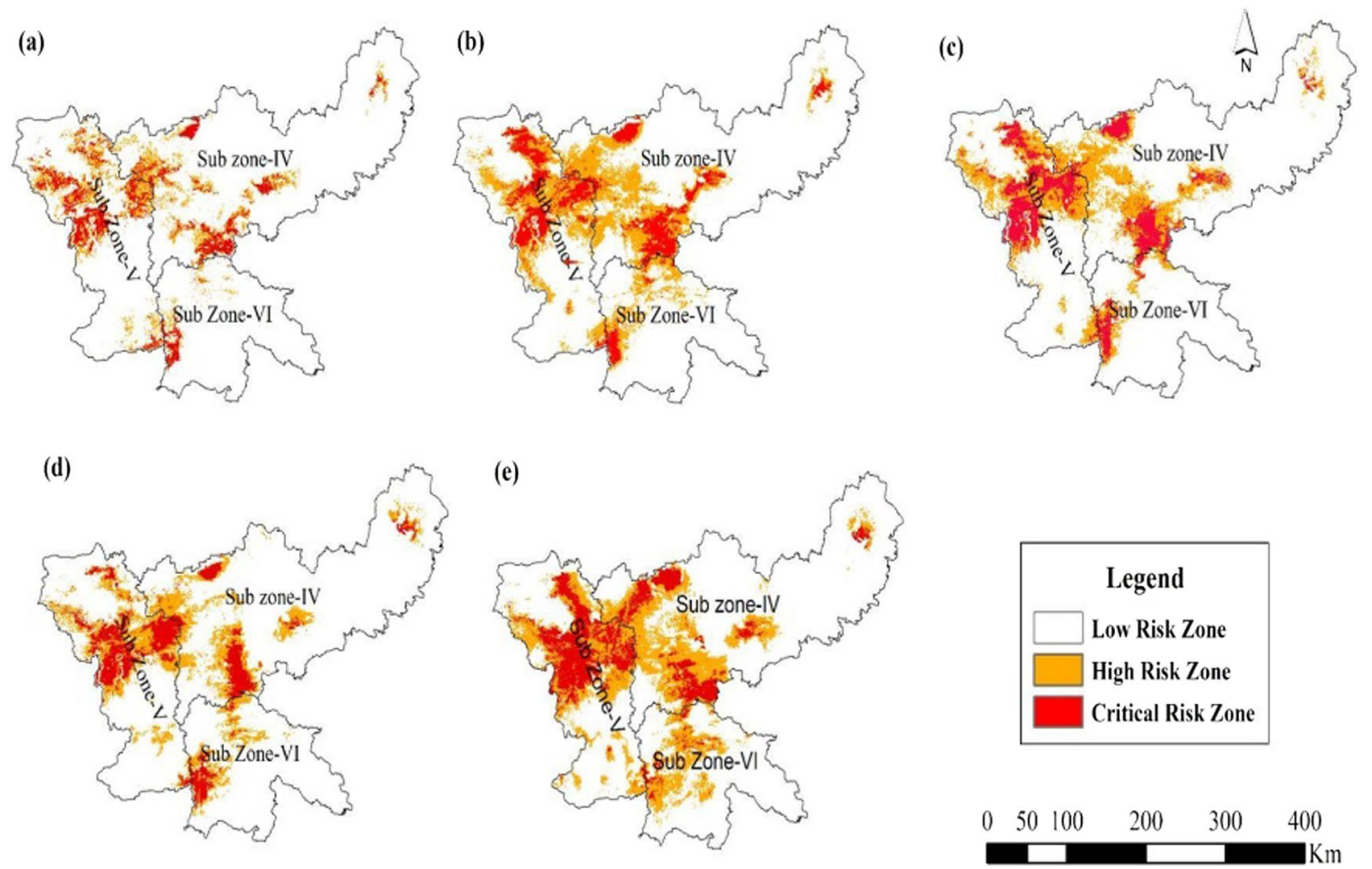

Fig. 5 Map showing potential distribution range of suitable habitats of L. camara for (a) 2020 and 2050 under RCPs (b) 2.6, (c) 4.5, (d) 6.0, and (e) 8.5 in Jharkhand. Map demonstrates further expansion in potential distribution range of L. camara by 2050 in Jharkhand encompassing the agro-climatic sub-zones IV, $\mathrm{V}$ and VI across all the RCPs i.e. 2.6, 4.5, 6.0 and 8.5 with maximum possible expansion under the scenario RCP 8.5. The probability of distribution is higher in high and critical risk zones than low risk zones

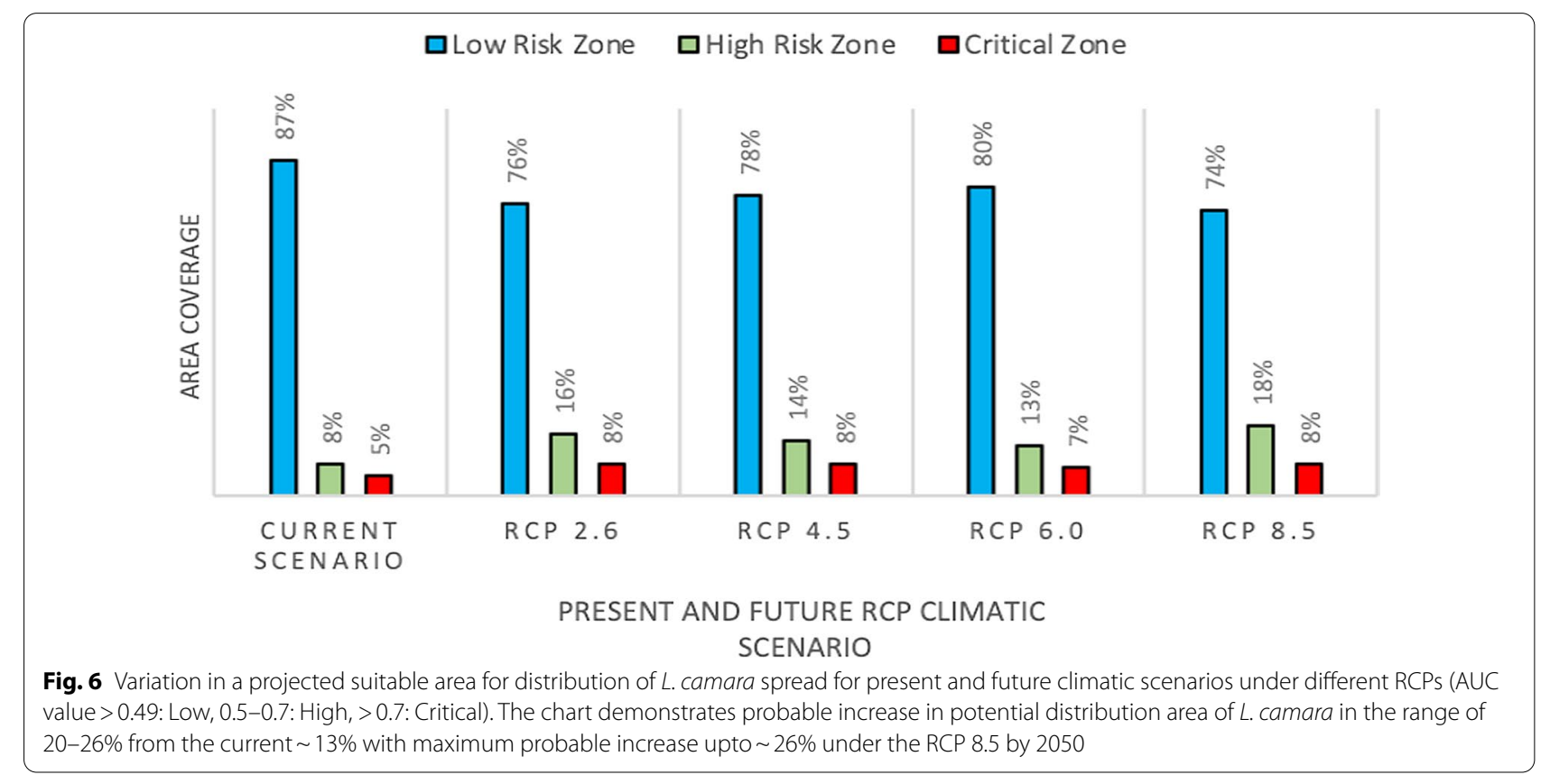




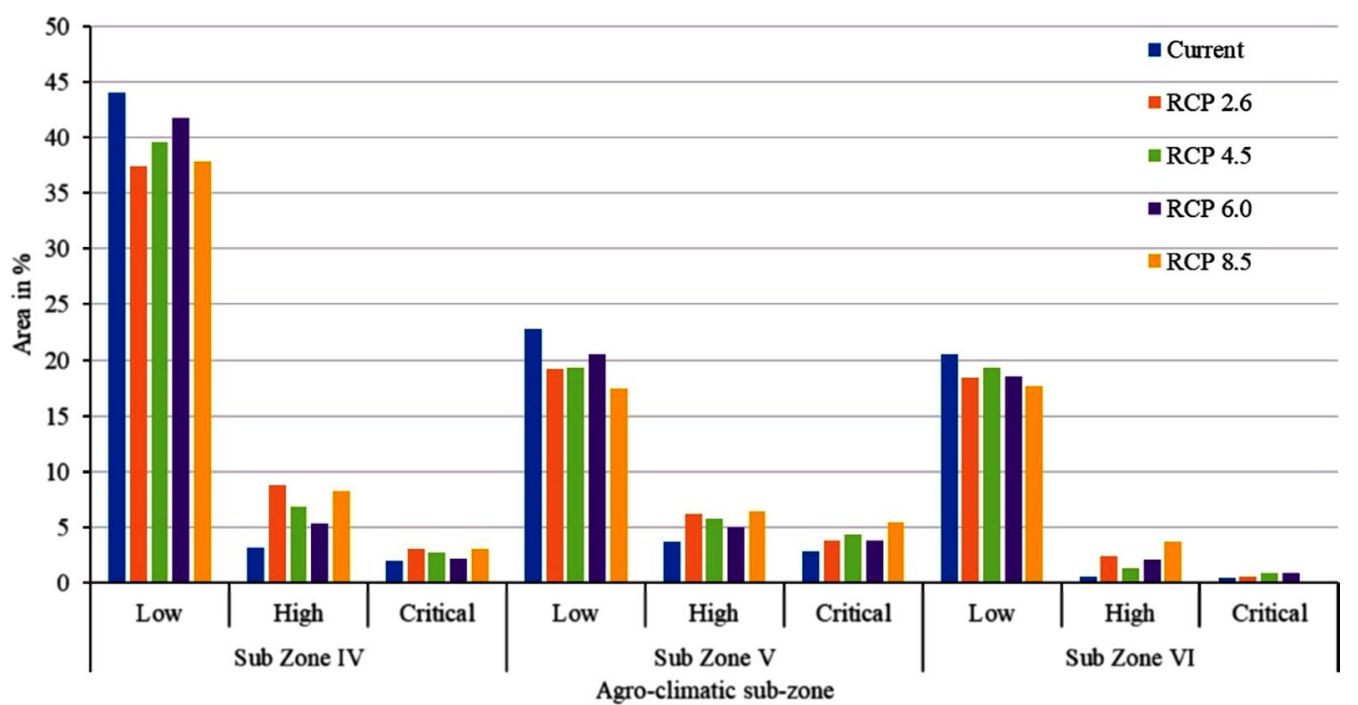

Fig. 7 Variation in the projected suitable habitat area (in percentage) for L. camara in different agro-climatic sub-zones of Jharkhand for the year 2020 and for 2050 under different RCPs i.e. 2.6, 4.5, 6.0, and 8.5 (AUC value<0.49: Low, 0.5-0.7: High, >0.7: Critical)

Agro-climatic zone wise projection of potential invasion sites The potential habitats to L. camara invasion exhibited susceptibility in larger parts of Jharkhand, across different agro-climatic sub-zones which will further be increased by 2050, across all the agro-climatic sub-zones in Jharkhand. The study revealed an increasing risk of $L$. camara invasion primarily in sub-zone $\mathrm{V}$, while the dominance of L. camara under sub-zones IV and V under the current scenario (Fig. 7). The probability of occurrence of L. camara invasion in future scenarios was observed approximately similar to the current scenario with prominence of distribution in sub-zone $\mathrm{V}$.
An average increase in the area of potential invasion was observed up to $2.39-7.29 \%$ in Jharkhand under HRZ compared to the existing scenario (0.54-3.18\%) across sub-zones IV, V and VI, while the area under CRZ increased up to $\sim 0.61-4.26 \%$ compared to the existing scenario (0.47-2.79\%) under CRZ across sub-zones in Jharkhand. In contrast, the area under low risk zones to invasion reduced by $9.81-11.19 \%$ under the future scenario compared to the current scenario. The probability of occurrence of L. camara was observed higher in HRZ and CRZ compared to LRZ across all the sub-zones. Bioclimatic variables Bio_4, Bio_7, Bio_9 and Bio_2 along

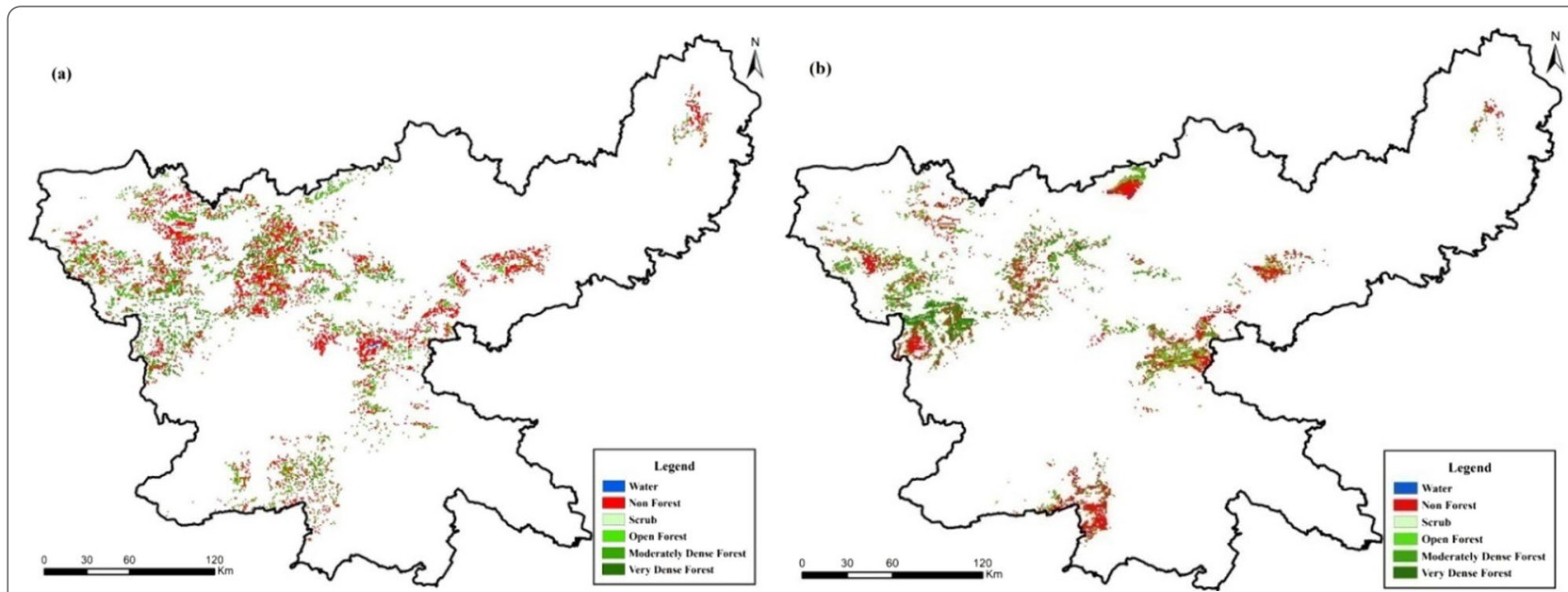

Fig. 8 Map depicting projected habitat distribution area of L. camara for (a) high risk zone (AUC: 0.50-0.70), (b) critical risk zone (AUC:>0.70) vulnerable to infestation under different forest cover in Jharkhand for the year 2020 


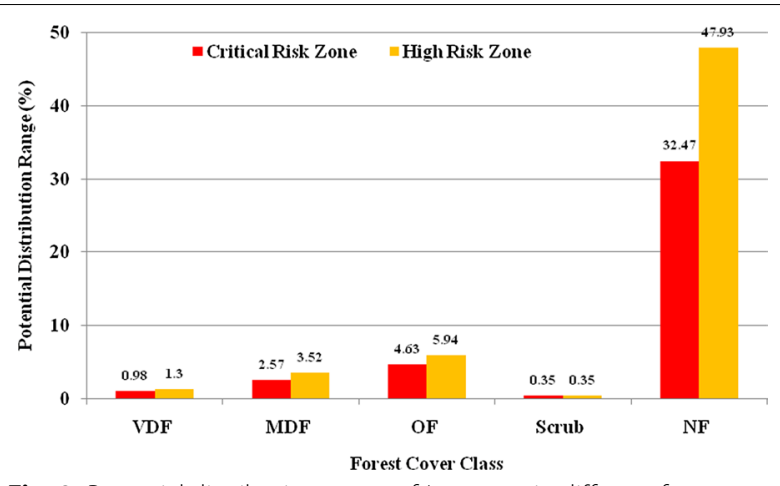

Fig. 9 Potential distribution range of $L$. camara in different forest cover classes under high risk zone (AUC value: $0.50-0.70$ ), and critical risk zone (AUC value $>0.70$ ) in Jharkhand under the current climate scenario. Chart demonstrates that the majority of the distribution occurs under the non-forest (NF) and open forest (OF) area

with Bio_15 (precipitation seasonality) most explain the distribution of $L$. camara. The distribution of $L$. camara varies with abundance of temperature and precipitation under different agro-climatic conditions across the sub-zones i.e., IV, V, and VI, highlighting the adoption across varied climatic conditions and terrains (Mungi et al. 2020). Our findings were consistent with Qin et al. (2015), indicating higher suitability of $L$. camara in tropical, subtropical, warm regions as in Jharkhand. The distribution of $L$. camara is characterised by warmer and humid climates, suggesting that it could invade habitats with similar niche conditions in other regions (Goncalves et al. 2014).

\section{Projected distribution of L. camara in forest landscape}

Approximately $44 \%$ of Indian forests, particularly those with habitats having warm, humid and fertile areas are prone to L. camara invasion (Mungi et al. 2020). The study highlighted a potential infestation of $L$. camara under high risk (HRZ), and critical risk category (CRZ) primarily in non-forest regions (HRZ: 47.93\%; 32.47\%) followed by open forest (HRZ: $5.94 \%$, CRZ: $4.63 \%$ ), moderately dense forest (HRZ: $3.52 \%, C R Z: 2.57 \%$ ), very dense forest (HRZ: 1.3\%, CRZ: 0.98\%), and least in scrub (HRZ: 0.35\%, CRZ: 0.35\%) (Figs. 8, 9). Approximately 91\% of the occurrence of L. camara was observed mostly in non-forest and open forest areas, in contrast to moderately dense and very dense forests (8-9\%). This endorsed the findings that it does not thrive under compact tree canopies of taller native forest species (Oosterhout et al. 2004; Negi et al. 2019). The higher distribution of L. camara was observed in open, sparse and disturbed forested landscapes as recorded during the field investigation while the distribution of $L$. camara diminishes significantly in dense forest areas with high canopy density (Negi et al. 2019). However, besides anthropogenic disturbances, the increased instances of forest fire due to climate change impact the compactness of the forests and modulate the expansion of invasive species (Brooks et al. 2004). The presence of invasive species (viz., L. camara) adjacent to forests poses a great threat to native forest composition as it may quickly invade the disturbed sites and limit the expansion of native vegetation by restricting natural regeneration (Hiremath et al. 2018), altering biodiversity, and wildlife habitat (Mao and Gogoi 2010; Berry et al. 2011).

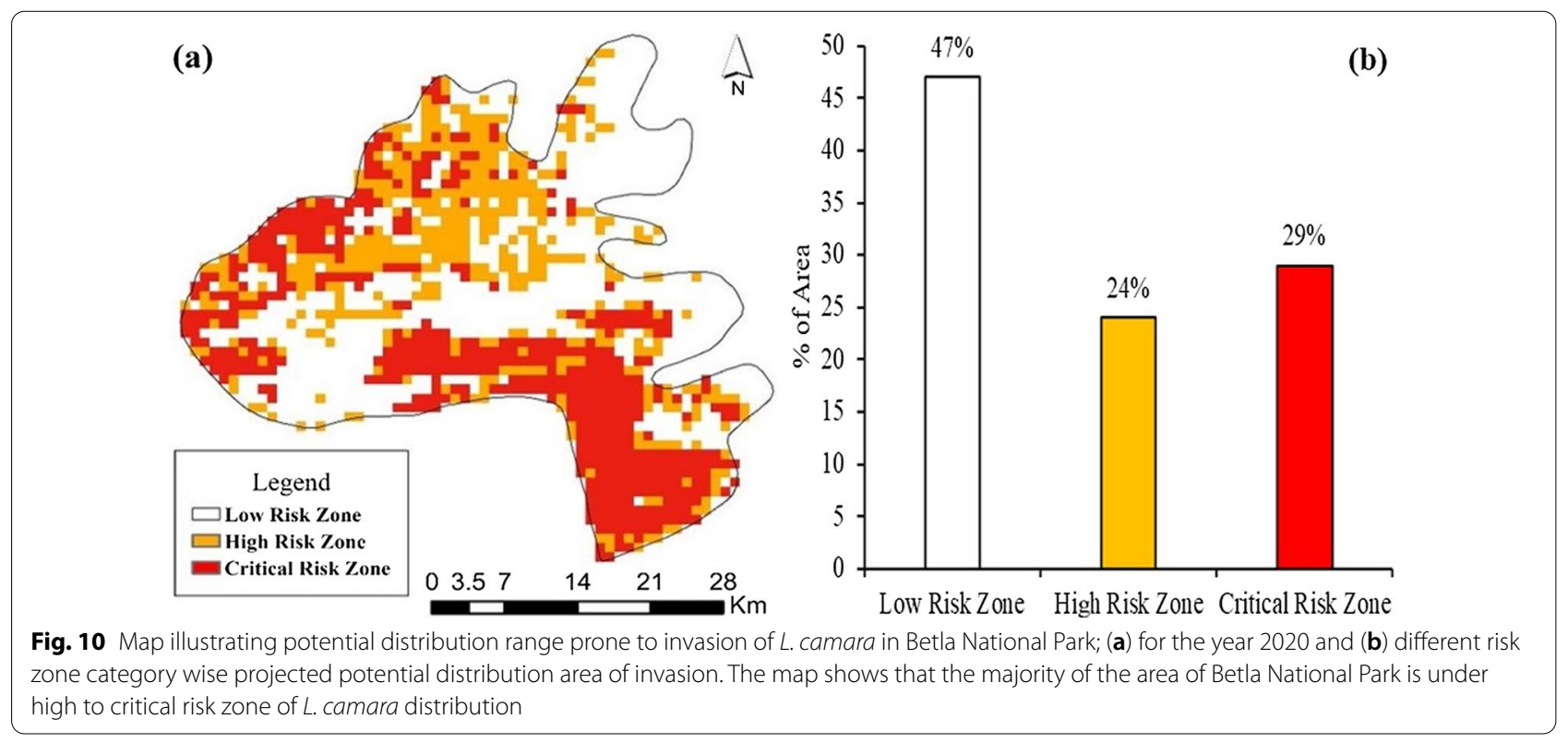


Table 2 LULC wise projected potential distribution range of L. camara under different risk zones (area in $\mathrm{km}^{2}$ )

\begin{tabular}{lcccccc}
\hline LULC class & Critical risk zone & \% of Total CRZ & High risk zone & \% of Total HRZ & Low risk zone & \% of Total LRZ \\
\hline Natural vegetation & 2762.24 & 66.05 & 3653.51 & 60.71 & $21,164.45$ & 30.45 \\
Water body & 20.35 & 0.49 & 22.00 & 0.37 & 2030.37 & 2.92 \\
Built-up & 20.19 & 0.48 & 50.19 & 0.83 & 4487.79 & 6.46 \\
Agriculture & 1234.10 & 29.51 & 2075.00 & 34.48 & $36,541.9$ & 52.57 \\
Other & 144.66 & 3.47 & 216.82 & 3.61 & 5290.43 & 7.60 \\
Total & 4181.54 & 100 & 6017.52 & 100 & $69,514.94$ & 100 \\
\hline
\end{tabular}

The higher invasion of $L$. camara in forest fringes compared to the core forest regions may be attributed to the high anthropogenic influencesthat augment the tendency of select species to invade more in disturbed forest regions (Richardson et al. 2004). In contrast, the core forest areas are mostly restricted parts and are less anthropogenically exposed, retaining the composition and virginity of the natural forest. Thus, core areas are less vulnerable to invasion than open and disturbed forests, which, due to high anthropogenic disturbances and open spaces, provide conditions that facilitate spread and success of L. camara (Stock et al. 2009). The open and disturbed spaces, forest fire, and anthropogenic factors are some of the major contributing factors that influence rapid expansion of $L$. camara invasion leading to depletion and altered composition of natives. Our findings indicate that the disturbed areas both in forest and agricultural landscapes stimulate the formation of invasive alien species (Theoharides and Dukes 2007), and that $L$. camara thrives better in disturbed forests (Prasad 2012) due to high adaptive capability to new niche dimensions under varying climatic conditions (Mungi et al. 2020).

\section{Invasion of L. camara in Betla National Park}

Research on invasive plant species in reserved forest areas in India is scarce and focuses mostly on L. camara (Hiremath et al. 2013). Betla National Park (BNP) is a very significant part of the Chotanagpur plateau as this is a designated protected area for conservation and promotion of tigers. It comprises $5.6 \%\left(1323.90 \mathrm{~km}^{2}\right)$ of the total forest area of Jharkhand while largely 53\% area of BNP, primarily in southern and western parts provides a highly suitable habitat for $L$. camara invasion (Fig. 10). The high to critical risk zones to L. camara invasion are primarily under high disturbances, whereas the core regions due to least anthropogenic disturbances are under low risk zones. Field investigations confirmed the thick and dense patches of L. camara spread across the park as the area was recurrently affected by open grazing, largely leading to limited resources to native species and augmenting further forest fire susceptibility through the provision of fuel beds (Berry et al.
2011). Approximately $43 \%$ area of Betla National Park has been observed high to very high fire incidences (Kumari and Pandey 2020) and is primarily affected by the invasion of $L$. camara (>75\% area) (Priyanka and Joshi 2013b). The extensive spread of $L$. camara in Betla National Park may also be attributed to the tourist movement that induces stressed conditions for native species simultaneously promoting the spread of invasion (Sunlu 2003). The richness of invasive species was consistently and significantly higher in tourist-dominated sites as compared to control areas (Anderson et al. 2015).

\section{Land use/land class (LULC) wise infestation analysis}

The impact of potential L. camara invasion on LULC exhibited a larger L. camara invasion in natural vegetation and agricultural land (Table 2). Considerable parts of river banks and ponds were affected by $L$. camara invasion (Vardien et al. 2012), as also established during the field verification, while in urban landscapes, $L$. camara was witnessed in abundance along roadsides, along railway tracks, and around open abundant areas (Thakur et al. 1992; Kohli et al. 2006). In villages, people use it as a protection fence around their homes on agriculture bund. A systematic outreach approach to create awareness among farmers, urban settlers, and tribals living in forest fringe villages needs to be conducted, regarding the harmful effects of L. camara and other similar weeds.

Our findings endorsed the effectiveness of Maxent in projecting potentially suitable habitat sites of $L$. camara. Areas predicted by the model are in consonance with $L$. camara distribution (Divakar et al. 2013; Ray and Ray 2014). The present study suggests an increasing invasion of $L$. camara to new areas (Vardien et al. 2012) but in contrasts to the finding of Goncalves et al. (2014). A possible explanation for this might be the varied study area size; since our study was restricted to Chotanagpur plateau eastern India, whereas Goncalves et al. (2014) had considered a global perspective.

Taken together these results suggested a wide invasion of $L$. camara across different landscapes of Jharkhand due to robust adaptive capability to survive and grow across varied environmental conditions particularly in 
the open and disturbed forest areas, and agriculture landscapes. The study indicated that distribution of $L$. camara does not follow any specific pattern; rather it is well spread across different agro-climatic sub-zones of Jharkhand. The findings of this investigation complement those of earlier studies that demonstrated the adaptability of $L$. camara to diverse environmental conditions and distribution across different landscapes and aid understanding of distribution ecology of L. camara. The strengths of this study included comprehensive analysis of distribution of L. camara in the region that represents forest cover, LULC and protection site wise examination and physical corroboration of projected potential distribution ranges through the extensive field surveys. These findings are directly relevant to the forest managers and have significant implications in forest management as it enables identification and prioritisation of areas already invaded or potential sites for future invasion threat of $L$. camara. The prior identification of potential sites at invasion risk shall be very useful in planning strategies to control expansion of L. camara in new spaces. The quantified estimation of the invaded area has direct implications in associated cost assessment for the conservation initiatives. With regard to the research methods, some limitations need to be acknowledged. Although the study has successfully demonstrated the potential distribution range of L. camara across different landscapes of Jharkhand, it has certain limitations in terms of use of coarser resolution of bioclimatic variables, which may have led to overestimation of projected areas. We have used Maxent in the present study, which is considered highly accurate and robust (Elith et al. 2006) but many researchers advocated applying an ensemble approach to address model overfitting issues and more accurate and precise area estimation (Araújo 2007). We recommend prioritisation of sensitive natural sites at the verge of greater invasion threat and adoption of native tree and grass based intervention models to address invasion issues, support richer biodiversity and environmental amelioration and outreach programs to educate people with the harmful effects of $L$. camara and other similar invasive species.

\section{Conclusion}

This study set out to assess the potential distribution areas of L. camara invasion in Jharkhand, a major part of Chotanagpur plateau region in the eastern India, for the years 2020 and 2050 under climate change scenarios. The study highlighted a wide distribution of $L$. camara across different landscapes of Jharkhand. The distribution of L. camara not only retains the existing area but shall also expand across the entire Jharkhand encompassing agro-climatic sub-zones IV, V and VI under future projections (2050). The investigation showed inability of L. camara to penetrate through the intact native virgin forests, in contrast to its abundant distribution along agricultural land and in open and disturbed forest areas including wide distribution in Betla National Park. The presence of L. camara in forest areas poses a great threat to native forest species and wildlife habitat in Chotanagpur plateau region as it restricts the regeneration and extension of natives. Another major finding of the study suggests urgent interventions to curtail its further expansion to support a better environment for the tigers in Betla National Park as well as reverse the ecosystem imbalance due to rapid invasion and removal of native species. We recommend prioritisation of sensitive natural sites at the verge of greater invasion threat and adoption of native tree and grass based intervention models to address invasion issues, support richer biodiversity and environmental amelioration and outreach programs to educate people with the harmful effects of L. camara and other similar invasive species.

\section{Abbreviations \\ IUCN: International Union for Conservation of Nature; GARP: Genetic Algo- rithm for Rule Set Production; RCP: Representative concentration pathways; FSI: Forest Survey of India; ASCII: American Standard Code For Information Interchange; ESRI: Environmental Systems Research Institute; SRTM: Shuttler Radar Topographic Mission; DEM: Digital elevation model; FAO: Food and Agriculture Organization; LULC: Land use/land cover; SVM: Support vector machine; NRSC: National Remote Sensing Centre; IPSL-CM5A-LR: Institut Pierre Simon Laplace Climate Model 5th Assessment-Low Resolution; ROC: Receiver operation characteristics; AUC: Area under curve; LRZ: Low risk zone; HRZ: High risk zone; CRZ: Critical risk zone; EO: Error of omission; EC: Error of commission; UA: User accuracy; PA: Producer accuracy; VDF: Very dense for- est; MDF: Moderate dense forest; OF: Open forest; NF: Non-forest; BNP: Betla National Park.}

\section{Acknowledgements}

The authors are grateful to ICFRE, Dehradun, Government of India for the funding provided for the project (IFP-083/A \& Extn-02/2016-2019). The first author is thankful to Director General, ICFRE, Dr. Rameshwar Das (former Director), Dr. S. A. Ansari (Ex Director, IFP), and Dr. N. Kulkarni (Director, IFP) for their help, and logistics support. The authors sincerely acknowledge the State Forest Department, Government of Jharkhand for their support in the field data collection, ground truth and field validation.

\section{Authors' contributions}

ST: Project conceptualization, Analysis, First draft and editing. SNM: Designing field layout, Field Survey. DK: Literature review, Field Survey. BK: Field Survey. SNV: Field survey. BG: Developing model through Maxent, GIS layers preparation. SkMR: GIS analysis, Forest Cover related analysis, Data validation, Writing. MK: Data cleaning, literature review. SG: Maxent modeling, field survey for validation. AK: Discussion, manuscript writing. All authors read and approved the final manuscript.

\section{Funding}

The funding for the project (IFP-083/A \& Extn-02/2016-2019) was provided by ICFRE, Dehradun.

Availability of data and materials

The data sets used and/or analysed during the current study are available from the corresponding author on reasonable request. 


\section{Declarations}

Ethics approval and consent to participate Not applicable.

\section{Consent for publication}

Not applicable.

\section{Competing interests}

The authors declare that they have no competing interests.

\section{Author details}

${ }^{1}$ Institute of Forest Productivity, Lalgutwa, Ranchi 835303, Jharkhand, India. ${ }^{2}$ Department of IT, Govt. of Jharkhand, Jharkhand Space Application Centre, Ranchi, India. ${ }^{3}$ Department of Geoinformatics, Central University of Jharkhand, Ranchi 835205, Jharkhand, India.

\section{Received: 2 February 2021 Accepted: 20 December 2021}

Published online: 26 January 2022

\section{References}

Anderson LG, Rocliffe S, Haddaway NR, Dunn AM (2015) The role of tourism and recreation in the spread of non-native species: a systematic review and meta-analysis. PLoS ONE 10(10):e0140833. https://doi.org/10.1371/ journal.pone.0140833

Araújo MB, New M (2007) Ensemble forecasting of species distributions. Trends Ecol Evol 22(1):42-47. https://doi.org/10.1016/j.tree.2006.09.010

Berry Z, Wevill K, Curran T (2011) The invasive weed Lantana camara increases fire risk in dry rainforest by altering fuel beds. Weed Res 51:525-533. https://doi.org/10.1111/j.1365-3180.2011.00869.x

Bhagwat SA, Breman E, Thekaekara T, Thornton TF, Willis KJ (2012) A battle lost? Report on two centuries of invasion and management of Lantana camara L. in Australia, India and South Africa. PLoS ONE 7(3):e32407

Bhuvan (2021) Internet source: www.bhuvan.nrsc.gov.in. Accessed 14 Jan 2021

Brooks ML, Carla MD, Richardson DM, Grace JB, Keeley JE, DiTomaso JM, Hobbs RJ, Mike P, David P (2004) Effects of invasive alien plants on fire regimes. Bioscience 54(7):677-688. https://doi.org/10.1641/0006-3568(2004) 054[0677:EOIAPO]2.0.CO;2

Daizy RB, Singh HP, Kohli RK, JoharV YS (2004) Management of invasive exotic weeds requires community participation. Weed Technol 18:1445-1448

Day MD, Wiley CJ, Playford J, Zalucki MP (2003) Lantana: current management, status and future prospects. Austr Centre Int Agric Res 5:1-20

Divakara BN, Prasad S, Das R (2013) Invasive Alien Plants of Jharkhand: a guide to the common man. Institute of Forest Productivity, Indian Council of Forestry Research and Education, India

Dobhal P, Kohli R, Batish D (2011) Impact of Lantana camara L. invasion on riparian vegetation of Nayar region in Garhwal Himalayas (Uttarakhand, India). J Ecol Nat Environ 3:11-22

Dufresne J, Foujols M, Denvil S (2013) Climate change projections using the IPSL-CM5 Earth System Model: from CMIP3 to CMIP5. Clim Dyn 40:2123-2216. https://doi.org/10.1007/s00382-012-1636-1

Elith J, Graham CH, Anderson RP, Dudik M, Ferrier S, Guisan A, Hijmans RJ, Huettmann F, Leathwick JR, Lehmann LG, Loiselle BA, Manion G, Moritz C, Nakamura M, Nakazawa Y, Overton JM, Peterson AT, Phillips SJ, Richardson K, Scachetti-Pereira R, Schapire RE, Soberon J, Williams S, Wisz MS, Zimmermann NE (2006) Novel methods improve prediction of species distributions from occurrence data. Ecography 29:129-151

FAO (2003) Digital Soil Map of the World. http://www.fao.org/soils-portal/soilsurvey/soil-maps-and-databases/faounesco-soil-map-of-the-world/en/. Accessed 10 Aug 2019

Fick SE, Hijmans RJ (2017) WorldClim 2: new 1-km spatial resolution climate surfaces for global land areas. Int J Climatol 37(12):4302-4315

FSI Report (2017) Forest Survey of India. https://fsi.nic.in/isfr2017/jharkhandisfr-2017.pdf

Goncalves E, Herrera I, Duarte M, Lampo M, Velasquaz G, Sharma GP, Rangel SG (2014) Global invasion of Lantana camara: has the climatic niche been conserved across continents? PLoS ONE 9:e111468. https://doi.org/10. 1371/journal.pone.0111468
Gooden B, French K, Turner PJ, Downey PO (2009) Impact threshold for an alien plant invader, Lantana camara L., on native plant communities. Biol Conserv 142:2631-2641

Hari Haran P (2017) Throwing a smart bait-study explores how Lantana camara might hog the attention of birds. Research Matters. Internet Source: https://researchmatters.in/article/throwing-smart-bait. Accessed 5 Jan 2020

Hiremath A, Sundaram B (2005) The fire-Lantana cycle hypothesis in Indian forests. Conserv Soc 3:26-42

Hiremath AJ, Ayesha P, Bharath S (2018) Restoring Lantana camara invaded tropical deciduous forest: the response of native plant regeneration to two common Lantana removal practices. Indian Forester 144(6):545-552

Hiremath AJ, Sundaram B (2013) Invasive plant species in Indian protected areas: conserving biodiversity in cultural landscapes. In: Foxcroft $L_{\text {, }}$ Pyšek P, Richardson D, Genovesi P (eds) Plant Invasions in Protected Areas: Patterns, Problems and Challenges. Invading Nature - Springer Series in Invasion Ecology, vol 7. Springer, Dordrecht. pp 241-266. https://doi.org/10.1007/978-94-007-7750-7_12

Hoffman JD, Narumalani S, Mishra D, Merani P, Wilson RG (2008) Predicting potential occurrence and spread of invasive plant species along the North Platte River, Nebraska. Invas Plant Sci Manage 1(4):359-367

IUCN (2001) 100 World's Worst Invasive Alien Species. Invasive Species Specialist Group, International Union for Conservation of Nature and Natural Resources. http://www.issg.org/booklet.pdf.

Jaryan V, Datta A, Unial SK, Kumar A, Gupta RC, Singh D (2013) Modelling potential distribution of Sapium sebiferum - an invasive tree species in Western Himalaya. Curr Sci 105(9):1282-1288

Kohli RK, Batish DR, Singh HP, Dogra KS (2006) Status, invasiveness and environmental threats of three tropical American invasive weeds (Parthenium hysterophorus L., Ageratum conyzoides L., Lantana camara L.) in India. Biol Invas 8:1501-1510

Kumar A, Kumar A, Adhikari D, Ravikanth G, Saikia P, Khan ML (2020) Ecological niche modelling for assessing potential distribution of Pterocarpus marsupium Roxb. in Ranchi, Eastern India. Ecol Res 35:1095-1105

Kumari B, Pandey AC (2020) Geo-informatics based multi-criteria decision analysis (MCDA) through analytic hierarchy process (AHP) for forest fire risk mapping in Palamau Tiger Reserve, Jharkhand state, India. J Earth Syst Sci 129:204. https://doi.org/10.1007/s12040-020-01461-6

Lin S (2007) The distribution and role of an invasive plant species, Lantana camara, in disturbed roadside habitats in Moorea, French Polynesia. UC Berkeley: UCB Moorea Class: Biology and Geomorphology of Tropical Islands. Retrieved from https://escholarship.org/uc/item/2cv2z8zr

Mao AA, Gogoi R (2010) Fire-induced invasion of an endemic plant species alters forest structure and diversity: a study from North-east India. Curr Sci 98(4):483-484

Meek CS, Richardson DM, Mucina L (2010) A river runs through it: land-use and the composition of vegetation along a riparian corridor in the Cape Floristic Region, South Africa. Biol Conserv 143:156-164

Mishra S, Kumar D, Tiwari S (2019) Selection of suitable digital elevation model for analysis of forest cover in different agro-climatic zones of Jharkhand, India. Trop Plant Res 6(1):54-62

Mishra SN, Kumar D, Kumar B, Tiwari S (2021) Assessing impact of varying climatic conditions on distribution of Buchanania cochinchinensis in Jharkhand using species distribution modeling approach. Curr Res Environ Sust 3:100025

Mungi NA, Quwreshi O, Jhala YV (2020) Expanding niche and degrading forests: key to the successful global invasion of Lantana camara (Sensuloto). Global Ecol Conserv 23:e01080

Navarro-Racines C, Tarapues J, Thornton P, Jarvis A, Ramirez-Villegas J (2020) High-resolution and bias-corrected CMIP5 projections for climate change impact assessments. Sci Data 7:7. https://doi.org/10.1038/ s41597-019-0343-8

Ncube B, Shekede M, Gwitira I (2020) Spatial modelling the effects of climate change on the distribution of Lantana camara in Southern Zimbabwe. Appl Geogr 117:102172. https://doi.org/10.1016/j.apgeog. 2020.102172

Negi GCS, Sharma S, Vishvakarma SCR, Samant SS, Maikhuri RK, Prasad RC, Palni LMS (2019) Ecology and use of Lantana camara in India. Bot Rev 85:109-130. https://doi.org/10.1007/s12229-019-09209-8 
Oosterhout EV, Clark A, Day MD, Menzies E (2004) Lantana Control Manual. Current management and control options for Lantana (Lantana camara) in the Australian state of Queensland. Department of Natural Resources, Mines and Energy, Brisbane, Queensland, Australia. Available from http://www.nrmqld.gov.au/pests/wons/Lantana) Accessed 28 Nov 2020

Padalia H, Srivastava V, Kushwaha SPS (2014) Modeling potential invasion range of alien invasive species, Hyptis suaveolens (L.) Poit. in India: comparison of MaxEnt and GARP. Ecol Inform 22:36-43

Patil BB, Janarthanam MK (2013) Distribution of some obnoxious weeds in north-western Ghats of India. Indian J Weed Sci 45(4):267-272

Phillips SJ, Dudík M, Robert ES (2020) [Internet] Maxent software for modeling species niches and distributions (Version 3.3.3). Available from http://biodiversityinformatics.amnh.org/open_source/maxent/. Accessed 15 Jan, 2020

Prasad AE (2012) Landscape-scale relationships between the exotic invasive shrub Lantana camara and native plants in a tropical deciduous forest in southern India. J Trop Ecol 28(1): 55-64

Priyanka N, Joshi PK (2013a) Modeling spatial distribution of Lantana camara: a comparative study. Can J Basic Appl Sci 1(2):100-117

Priyanka N, Joshi PK (2013b) Assessment of plant invasion and forest fire linkages, A case study of L. camara. Int J Sci Technol Res 2(10):40-46

Qin Z, Zhang JE, Tommaso AD, Wang RL, Liang KM (2015) Predicting the potential distribution of Lantana camara L. under RCP scenarios using ISI-MIP models. Clim Change 134:193-208. https://doi.org/10.1007/ s10584-015-1500-5

Raghubanshi AS, Tripathi A (2009) Effect of disturbance, habitat fragmentation and alien invasive plants on floral diversity in dry tropical forests of Vindhyan highland: a review. Trop Ecol 50(1):57-69

Raghubanshi AS, Rai LC, Gaur JP, Singh JS (2005) Invasive alien species and biodiversity in India. Curr Sci 88(4):539-540

Rajput R, Adhikari D, Verma S, Saikia P, Kumar A, Grant KR, Dayanandan A, Kumar A, Khare PK, Khan ML (2020) Climate models predict a divergent future for the medicinal tree Boswellia serrata Roxb. in India. Glob Ecol Conserv 23:e01040

Ramaswami G, Sukumar R (2014) Lantana camara L. (Verbenaceae) invasion along streams in a heterogeneous landscape. J Biosci 39:717-726. https://doi.org/10.1007/s12038-014-9465-5

Ray A, Ray R (2014) Rapid divergence of ecotypes of an invasive plant. AoB Plants 6:052. https://doi.org/10.1093/aobpla/plu052

Richardson DM, Rouget M, Henderson L, Nel JL (2004) Invasive alien plants in South Africa: macroecological patterns, with special emphasis on the Cape Floristic Region. In: Proceedings of the 10th MEDECOS Conference, April 25-May 1, Mill Press, Rotterdam

Shackleton RT, Witt Arne BR, Aool W, Pratt Corin F (2017) Distribution of the invasive alien weed, Lantana camara, and its ecological and livelihood impacts in eastern Africa. Afr J Range Forage Sci 34(1):1-11. https://doi. org/10.2989/10220119.2017.1301551

Sharma GP, Raghubanshi AS (2006) Tree population structure, regeneration and expected future composition at different levels of Lantana camara L. invasion in the Vindhyan tropical dry deciduous forest of India. Lyonia 11(1):27-39

Sharma GP, Raghubanshi A, Singh JS (2005) Lantana invasion: an overview. Weed Biol Manage 5:157-165. https://doi.org/10.1111/j.1445-6664. 2005.00178.x

Singh JS, Singh SP (1992) Forests of Himalaya: structure, functioning and impact of man. Gyanodaya Prakashan, Nainital. pp. 294

Stock D, Johnson K, Clark A, Oosterhout EV (2009) Lantana best practice manual and decision support tool. Yeerongpilly: The State of Queensland, Department of Employment, Economic Development and Innovation

Sunlu U (2003) Environmental impacts of tourism In: Camarda D, Grassini L (eds) Local resources and global trades: environments and agriculture in the Mediterranean region. Bari: CIHEA. p. 263-270 (Options Méditerranéennes: Série A. Séminaires Méditerranéens; no. 57)

Swarbrick JT (1986) History of the lantanas in Australia and origins of the weedy biotypes. Plant Prot Q 1:115-121

Thakur ML, Ahmad M, Thakur RK (1992) Lantana weed (Lantana camara var. aculeata Linn.) and its possible management through natural insect pests in India. Indian Forester 118:466-488
Theoharides KA, Dukes JS (2007) Plant invasion across space and time: factors affecting nonindigenous species success during four stages of invasion. New Phytol 176:256-273

Vardien W, Richardson DM, Foxcroft LC, Thompson GD, Wilson JRU, Le Roux JJ (2012) Invasion dynamics of Lantana camara L. (sensu lato) in South Africa. South Afr J Bot 81:81-94. https://doi.org/10.1016/j.sajb.2012.06. 002. http://www.sciencedirect.com/science/article/pii/S025462991 2000701

Witt A, Beale T, van Wilgen BW (2018) An assessment of the distribution and potential ecological impacts of invasive alien plant species in eastern Africa. Trans R Soc South Afr 73(3):217-236. https://doi.org/10.1080/ 0035919X.2018.1529003

\section{Publisher's Note}

Springer Nature remains neutral with regard to jurisdictional claims in published maps and institutional affiliations.

\section{Submit your manuscript to a SpringerOpen ${ }^{\circ}$ journal and benefit from:}

- Convenient online submission

- Rigorous peer review

- Open access: articles freely available online

- High visibility within the field

- Retaining the copyright to your article

Submit your next manuscript at $\boldsymbol{\nabla}$ springeropen.com 